\title{
THE ATTITUDE OF THE PRO-ARIAN BISHOPS TOWARDS THE EMPEROR IN THE PERIOD OF RECEPTION OF THE NICENE CHRISTOLOGY (325-381)
}

The Nicene Council did not put an end to the Arian polemic. After the Council there came a long period of the struggle for reception of the Nicene Christology. Half a century after Nicaea was a period necessary for the whole reception of a new rational language in theology ${ }^{1}$. In this period the episcopacy of the Eastern Church was divided into different groups ${ }^{2}$. As a result, such a division caused the groups' fight with each other. Soon, the controversy became a subject of interest for the Emperor since it was perceived as a threat for the imperial unity. For this reason, the custom of the Emperor to intervene in the ecclesiastical affairs, which arose as a result of legalization of the Christianity, began to increase even in the area of doctrine ${ }^{3}$. Such situation evoked a reaction of bishops and became an opportunity for defining the role of the Emperor in the Church. There are two main standpoints in this regard in the fourth century: one of the pro-Arian bishops and the other of the anti-Arian bishops ${ }^{4}$.

We use terms "pro-Arian" and "anti-Arian" so as not to apply the terms "Arian" and "Orthodox". Following Timothy D. Barnes, we accept that the term "Arians" is a term of abuse. In the early fourth century the crucial ecclesiastical division lay between those who considered Arius to be a heretic and those who thought that his views lay within the limits allowed by the traditional teaching of the Church, although he framed some extreme formulations ${ }^{5}$. The latter pro-Arian group seems to contain a majority of eastern bishops who were

* Oleksandr Kashchuk Ph.D. - Assistant Professor in the Department of History of the Middle Ages and Byzantium at the Faculty of History of Lviv Ivan Franko National University and Senior Lecturer in the Department of Theology at the Faculty of Philosophy and Theology of Lviv Ukrainian Catholic University; e-mail: oleksandr@wp.pl.

${ }^{1}$ Cf. B. Sesboüé, Bóstwo Syna i Ducha Świętego (IV wiek), w: Historia dogmatów, I: Bóg zbawienia, red. B. Sesboüé - J. Wolinski, thum. P. Rak, Kraków 1999, 230-231.

${ }^{2}$ Cf. H. Chadwick, The Early Church, London 1990, 129; L.G. Patterson, Nikaia to Constantinople: the Theological Issues, GOTR 27 (1982) 376.

${ }^{3}$ Cf. Chadwick, The Early Church, p. 125 and 131-133.

${ }^{4}$ Cf. G.H. Williams, Christology and Church-State Relations in the Fourth Century (I), ChH 20 (1951) fasc. 3, 3-5.

${ }^{5}$ Cf. T.D. Barnes, Athanasius and Constantius. Theology and politics in the Constantinian Empire, Cambridge - London 1993, 15. 
too deeply entrenched in a mildly subordinationist Trinitarian theology. It was difficult for them to accept the ó $\mu o o v \sigma o s$, with its un-Scriptural origin and its Sabellian shade. They took part in councils (after Nicaea) and joined in composing new creeds, but they were not filled with hatred to Nicaea. Though often branded as Arians, they were not really those with the exception of some radical subordinationist theologians. The pro-Arian bishops, for the most part, disclaimed the name of Arius (c. 256-336) ${ }^{6}$. From that point of view, "proArian" does not always mean heretical ${ }^{7}$. However, it should be noticed that the pro-Arian adversaries of Athanasius (c. 295-373) were often dishonourable people ${ }^{8}$. On the other hand, it is not appropriate to apply the term "Orthodox" to all the adversaries of Arius, because there were bishops among them whose theological views were not completely orthodox, e.g. Marcellus of Ancyra (c. 280 - c. 374$)$.

There is a significant number of studies that explore the relations between the Church and the state in the fourth century ${ }^{9}$, but we are still in need of clear and systematic comprehension of the pro-Arian bishops' attitude towards the Christian Emperor. The chief purpose of this paper is to illustrate the proArian bishops' standpoint concerning the Emperor in the Church. The paper is divided into three parts. The first part as a short introduction briefly presents the ideological and historical background of the framing of the pro-Arian attitude towards the Emperor. In the second part we focus on the principles of the pro-Arian political theory. The aim of the third part is to show the place of the pro-Arian synods as the clearest form of manifestation of the pro-Arian attitude towards the Emperor.

${ }^{6}$ Cf. Athanasius, De synodis 22-23; Socrates, HE II 10; II 39-40. See J.N.D. Kelly, Early Christian Creeds, London 1972, 257 and 261; E. Gibbon, The Decline and Fall of the Roman Empire, vol. 1: 180 A.D. - 395 A.D., New York 1960, 688; W.H.C. Frend, The Rise of Christianity, Philadelphia 1984, 524; M. Fiedrowicz, Teologia Ojców Kościoła. Podstawy wczesnochrześcijańskiej refleksji nad wiarq, Kraków 2009, 236-242; P.F. Beatrice, The Word "Homoousios" from Hellenism to Christianity, ChH 71 (2002) 243-272.

${ }^{7}$ In 359 Athanasius realized, that most of those whom he had considered as heretics were allies in theology. Cf. Barnes, Athanasius and Constantius, p. 122-123, 134-135 and 152.

${ }^{8}$ Cf. Socrates, HE I 27; I 23; I 35; Sozomenus, HE II 22; Athanasius, De synodis 21. See J. Brendan, The Arian controversy: A purely theological dispute or a political controversy?, "Phronema" 12 (1997) 64-65. It should be noticed that according to Sozomenus (c. 400-450), Emperor Constantine manifested resentment against Eusebius of Nicomedia, because he had previously adopted the opinions of the tyrant, and had engaged in his plots. Cf. Sozomenus, HE I 21.

${ }^{9}$ The most important are: Barnes, Athanasius and Constantius, passim; idem, Constantine and Eusebius, Cambridge Mass. - London 1981; F. Dvornik, Early Christian and Byzantine Political Philosophy: Origins and background, vol. 2, Washington 1966; D.J. Geanakoplos, Church and State in the Byzantine Empire: A Reconsideration of the Problem of Caesaropapism, ChH 34 (1965) 381-403; R.M. Novak, Christianity and the Roman Empire: Background texts, Harrisburg 2001; H. Rahner, Church and State in Early Christianity, trans. L.D. Davis, San Francisco 1992; Williams, Christology and Church-State Relations (I), p. 3-33; idem, Christology and Church-State Relations in the Fourth Century (II), ChH 20 (1951) fasc. 4, 3-26. 
1. The ideological and historical background of the problem. The pro-Arian political theory was formulated in the fourth century, especially in the writings of Eusebius of Caesarea (c. 263-339), a bishop and ecclesiastic counsellor of Emperor Constantine the Great (c. 273-337, the emperor since 306). Eusebius directly and indirectly transformed the ancient political concepts into the early Christian theory of authority. He made use of the ideas of the Hellenistic philosophy, the motifs of the Holy Scripture, still alive roman idea of the Emperor as the Highest Priest and also the ante-Nicene pattern of the relationship between the Church and the state ${ }^{10}$.

The kingship in the Hellenistic period was regarded primarily as consisting

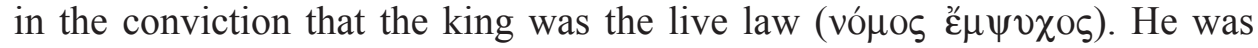
deemed as the divine or natural law. That law became incarnated in a man who was thereby made unique among men. He was the mediator to society of the law of the universe. Such a king provided the perfect government. The cult of the Hellenistic kings was known in the ancient times. The views on the royalty of this kind were also intrinsic to Persia and especially to Assyria ${ }^{11}$.

The aspects of Assyrian royalty were familiar to the Israelites. They were of great importance in the Hebrew view of society. For example, the leader of the Israelites Moses brings the law of God, to which he has an access himself. It is similar to the Hellenistic idea of the live law, which appears very early in the literature of the Hebrews: the Yahveh is the king of Israel who represents his will with a help of a man (Ex 3, 10-17; 4, 10-17; 19, $3-20,22)^{12}$. The idea of the live law was still more apparent in the times of Kings. After Samuel had abdicated his office as a judge, Yahveh was no longer the king of Israel ruling through a man who acted impersonally as Yahveh's mouth-piece. A man would be a king of Israel as incarnate law of God (1Sam 12). The conception of the royal office, described in connection with the first king Saul had an agreement with the oriental monarchy. The king was spirit-filled and spirit-led link between Yahveh and his people (1Sam 10) ${ }^{13}$. After the spirit of Yahveh had departed from Saul (1Sam 16, 14), this spirit began to be operative upon David (1Sam 16, 13), established by Yahveh as a king over Israel (2Sam 5, 12). David was the incarnate spirit of Yahveh to carry out Yahveh's work of justly ruling the people (2Sam $23,1-7 ; 15,1-6 ; 19,27 ; 14,17.20)^{14}$.

The Hellenistic political ideas were also transferred to Roman political culture. In the Roman Empire the imperial cult was grafted into the traditional patterns of Graeco-Roman religion. The imperial cult was treated as an

\footnotetext{
${ }^{10}$ Cf. Geanakoplos, Church and State in the Byzantine Empire, p. 384.

${ }^{11}$ Cf. J.J. Farber, The Cyropaedia and Hellenistic Kingship, "The American Journal of Philology" 100 (1979) 497-514; E.R. Goodenough, Kingship in Early Israel, JBL 48 (1929) 3/4, 169-177; A. Momigliano, How Roman Emperors became Gods, “American Scholar" 55 (1986) fasc. 2, 185.

${ }^{12}$ Cf. Goodenough, Kingship in Early Israel, p. 178-182.

${ }^{13}$ Cf. ibidem, p. 185-189.

${ }^{14}$ Cf. ibidem, p. 192-194.
} 
expression of political allegiance. The Emperor as the Highest Priest regulated the religious life of the subjects. Even the Christian Emperors were in no hurry to eliminate the imperial cult ${ }^{15}$.

During the ante-Nicene period of martyrs early Christians mostly recognized the Roman State, even when it persecuted them. The Church was faithful to the teaching of Scripture that the earthly authority had been given from God (Jn 19, 11; Rom 13, 1-2; Dan 2, 37) ${ }^{16}$. But the Church remembered the teaching of Christ that a man should render God's to God and the Emperor's to the Emperor (Mt 22, 21; 10, 18) ${ }^{17}$. That is why the Church could not accept the Emperor as the Highest Priest and Christians could not worship him giving an expression of reverence $^{18}$. By contrast, the Church expected the protection from the Empire ${ }^{19}$.

In the fourth century after the Emperor had become a Christian convert, Christians were confused with distinguishing between what they should render to the Christian Emperor and what to Christ. Christians in the first moments of rejoicing uncritically accepted the imperial patronage of Constantine the Great. They could even praise Constantine as the herald of Providence sent by God ${ }^{20}$.

Constantine the Great firmly established toleration of the Church. However, he could not escape being involved further into the Church's affairs. His regard in this aspect was based on his political conviction that the unity of the Empire could be maintained only with the help of the Church ${ }^{21}$. Constantine recognized

${ }^{15}$ Cf. D.L. Jones, Christianity and Emperor Worship from Hadrian to Constantine, "Perspectives in Religious Studies" 6 (1979) fasc. 1, 43; Momigliano, How Roman Emperors became Gods, p. 186-192. On the role of the Emperor in the Priestly Colleges see F. Millar, The Emperor in the Roman World (31 BC-AD 337), New York 1984, 355-361.

${ }^{16}$ Cf. Clemens Romanus, Epistola ad Cirinthios LXI; Justinus, Apologia I 17; Tertullianus, Apologeticum 28, 3 - 33, 4; Eusebius Caesariensis, HE IV 26, 5-11. See Rahner, Church and State in Early Christianity, p. 13; Williams, Christology and Church-State Relations (I), p. 6.

${ }^{17}$ Cf. Justinus, Apologia I 17. See Rahner, Church and State in Early Christianity, p. 3-4; Dvornik, Early Christian and Byzantine Political Philosophy, vol. 2, p. 558-610.

${ }^{18}$ Cf. Theophilus, Ad Autolycum I 11; Tertullianus, Apologeticum 28, 3 - 33, 4. See Jones, Christianity and Emperor Worship from Hadrian to Constantine, p. 34-44; Rahner, Church and State in Early Christianity, p. 7-9; Williams, Christology and Church-State Relations (I), p. 7-8.

${ }^{19}$ There was an event that Church applied to Emperor Aurelianus (270-275) for the aid, when Paul of Samosata (c. 200 - c. 275), having been excommunicated, refused to surrender the church building. The Emperor ordered the building to be given to those to whom the bishops of Italy and of the city of Rome should adjudge it. Thus Paul was driven out of the church by the worldly power. Cf. Eusebius Caesariensis, HE VII 30.

${ }^{20}$ Cf. W.H.C. Frend, Constantine's Settlement with the Church and its Legacy, "Modern Churchman" 6 (1962) fasc. 1, 41-42; Rahner, Church and State in Early Christianity, p. 42; Williams, Christology and Church-State Relations (I), p. 4-6 and 14; Brendan, The Arian Controversy, p. 56; Dvornik, Early Christian and Byzantine Political Philosophy, vol. 2, p. 612-614.

${ }^{21}$ Cf. Socrates, HE I 27; Sozomenus, HE I 16; Eusebius Caesariensis, Vita Constantini II 55; IV 42. See Rahner, Church and State in Early Christianity, p. 40-42; Novak, Christianity and the Roman Empire, p. 171; Brendan, The Arian Controversy, p. 56-57; Williams, Christology and Church-State Relations (I), p. 5. 
himself in the Church as a bishop to overlook whatever was external to the Church $^{22}$ and as the instrument for the accomplishment of God's will ${ }^{23}$.

For Constantine, the unity of the Church and, in consequence, of the Empire, was far more important than the establishment of the true doctrine ${ }^{24}$. Moreover, he was ignorant of the more intricate details of the Christian religion. After the heresy of Arius had arisen, the Emperor never comprehended the danger of his doctrine $^{25}$. Theoretically Constantine was convinced that the Church should be completely free from the state interference in her own proper area of the competence $^{26}$. The Emperor gave the legal force to the decisions of bishops passed at their synods ${ }^{27}$. However, it was only a theory.

The manifestation of the hidden claims to authority over the Church became clearly apparent after the synod had been convened at Antioch between 326 and 329. According to the decision of the synod Constantine exiled bishop Eustathius (c. 300-377) and his allies who remained loyal to the Creed of Nicaea $^{28}$. Constantine also threatened Athanasius with banishment because he had refused communion to Arius and his adherents ${ }^{29}$. In 335 at Tyre Athanasius was exiled to Treves, the city of Gaul ${ }^{30}$. Constantine wrote to the synod of Tyre if anyone had resisted his order, he would have taught him that it was not appropriate to resist the Emperor's decrees when issued in defence of the truth ${ }^{31}$. Thus, the beginning of limitation of the Church's independence became clear ${ }^{32}$.

${ }^{22}$ Cf. Eusebius Caesariensis, Vita Constantini IV 24. See ibidem I 44.

${ }^{23}$ Cf. ibidem II 28. See Dvornik, Early Christian and Byzantine Political Philosophy, vol. 2, p. 637-638.

${ }^{24}$ The controversy started at Alexandria and then was spread abroad sowing disagreement among the Christians. Cf. Eusebius Caesariensis, Vita Constantini II 62. See C. Haas, The Arians of Alexandria, VigCh 47 (1993) 234-235.

${ }^{25}$ Cf. Eusebius Caesariensis, Vita Constantini II 64-72. See Williams, Christology and Church-State Relations (I), p. 4; Novak, Christianity and the Roman Empire, p. 171-172; Brendan, The Arian Controversy, p. 56-57; Rahner, Church and State in Early Christianity, p. 44-45.

${ }^{26}$ Cf. Eusebius Caesariensis, Vita Constantini III 20. See Sozomenus, HE I 25.

${ }^{27}$ Cf. Eusebius Caesariensis, Vita Constantini IV 27. See Dvornik, Early Christian and Byzantine Political Philosophy, vol. 2, p. 640-643; Barnes, Constantine and Eusebius, p. 244.

${ }^{28}$ Cf. Athanasius, Historia Arianorum 4; Socrates, HE I 24; Sozomenus, HE II 19. On deposition of Eustathius between 326 and 329 see R.W. Burgess, The Date of the Deposition of Eustathius of Antioch, JTS 51 (2000) 151-153. Barnes (Athanasius and Constantius, p. 172) states that in reality Constantine denied himself the right to try bishops, who could be condemned and deposed only by a council of their peers. After a bishop had been tried and condemned by his peers, it was both proper and necessary for the Emperor to enforce his deposition by means of exile, using force if necessary.

${ }^{29} \mathrm{Cf}$. Athanasius, Apologia 59; Socrates, HE I 27.

${ }^{30}$ Cf. Socrates, HE I 35; Theodoretus, HE I 29. See Barnes, Athanasius and Constantius, p. $13-$ 14; idem, Constantine and Eusebius, p. 239-240.

${ }^{31}$ Cf. Eusebius Caesariensis, Vita Constantini IV 42.

${ }^{32}$ Cf. Rahner, Church and State in Early Christianity, p. 48. More on Constantine's intervention into Church affairs see H.A. Drake, Constantine and the Bishops. The Politics of Intolerance, Baltimore - London 2000. 
Two years later just before dying he received baptism on his deathbed by the laying on of hands of the pro-Arian bishop Eusebius of Nicomedia $(\dagger \text { c. } 341)^{33}$. At the time the adherents of Arius in the Eastern Church had almost complete supremacy ${ }^{34}$.Constantine did not manage to unite the $\mathrm{Church}^{35}$.

After Constantine's death it was his young son Constantius (317-361, the emperor since 337) who would wage the real war with the Church on the ground made by his father. Constantius continued his father's policy of the establishing religious unity on the grounds of a creed acceptable to as many as possible and valid throughout the Empire ${ }^{36}$. Constantius was dependent on the pro-Arian clergy led by Eusebius of Nicomedia ${ }^{37}$.

Constantius like his father, was not profoundly initiated into Christian mysteries $^{38}$. His Christianity was not pure. Probably for Constantius Christian God was the Supreme Deity without distinctively Christian attributes ${ }^{39}$. The most he could understand and personally accept was that Christ was like God (örotos), but was not the very God ${ }^{40}$.

Constantius was impressed by the pagan monotheist Themistius (317-388) who represented ancient conceptions of the relationship of the Emperor to Deity ${ }^{41}$. Constantius' allies convinced him that his decision was the judgment of the Supreme Deity, and was not of any human mind ${ }^{42}$. According to Athanasius, in 355 in Milan Constantius even stated that his solutions were laws also in the ecclesiastical sphere ${ }^{43}$. Constantius' died in 361.

${ }^{33}$ Cf. Eusebius Caesariensis, Vita Constantini IV 62; Socrates, HE I 39; Sozomenus, HE II 39.

${ }^{34}$ Cf. Socrates, HE I 38; Sulpitius Severus, Chronicorum lib. II 35-36. See Barnes, Constantine and Eusebius, p. 225-226.

${ }^{35}$ Cf. Barnes, Constantine and Eusebius, p. 244.

${ }^{36}$ Cf. Rahner, Church and State in Early Christianity, p. 49 and 58-59; Barnes, Athanasius and Constantius, p. 169; Frend, The Rise of Christianity, p. 536.

${ }^{37}$ Cf. Theodoretus, HE II 2; Athanasius, Historia Arianorum 70. See Gibbon, The Decline and Fall of the Roman Empire, p. 695.

${ }^{38}$ Cf. Sulpitius Severus, Chronicorum lib. II 42-43; Theodoretus, HE II 2. See Gibbon, The Decline and Fall of the Roman Empire, p. 694.

${ }^{39} \mathrm{Cf}$. Ammianus Marcellinus, Res gestae XXI 13, 14.

${ }^{40} \mathrm{Cf}$. Williams, Christology and Church-State Relations (I), p. 23.

${ }^{41}$ Cf. ibidem, p. 22-24; Dvornik, Early Christian and Byzantine Political Philosophy, vol. 2, p. 622-628; According to Themistius, the authority of the Emperor comes not from the people or the army, but from the God. The Empire is the reflection of the heaven and the Emperor is personified law. The Emperor is to be like God in all respects, a heavenly being. But Themistius underlined the divinity of the Emperor's office, not of the very Emperor. See S.A. Stertz, Themistius: A Hellenic Philosopher-Statesman in the Christian Roman Empire, "Classical Journal" (1976) 350-357.

${ }^{42}$ Cf. Ammianus Marcellinus, Res gestae XV 8, 9. See Rahner, Church and State in Early Christianity, p. 61; Williams, Christology and Church-State Relations (I), p. 24.

${ }^{43} \mathrm{Cf}$. Athanasius, Historia Arianorum 33. T.D. Barnes (Athanasius and Constantius, p. 106-108 and 131) makes an objection to this statement of Athanasius. He asserts, that Athanasius had preconceived opinion of Constantius. According to him this hostile picture does not correspond either to the complicated realities of ecclesiastical politics or to the sentiments of the majority of eastern 
Another Emperor who was active and strenuous in the Church affairs was Valens (328-378, the emperor since 364). He favoured the pro-Arian doctrine ${ }^{44}$. Valens, like Constantius, was inspired by the political philosophy of Themistius ${ }^{45}$. The Emperor became the very personification of religious despotism brutally exercised ${ }^{46}$. For example, the imperial edict issued by him

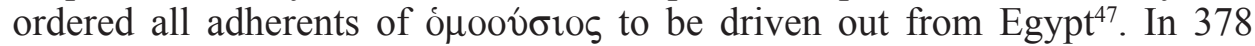
Valens was slain ${ }^{48}$. The Church remained divided.

So, on the grounds of aforesaid we may assert that the Christian Emperors for the great part intervened in the field of the Church affairs and supported the views of the pro-Arian bishops. Therefore, the problem concerning the Churchstate relations arose. The rival groups of bishops created their own standpoint concerning the role of the Emperor in the Church. In this way the Arian controversy from the purely theological discussion ${ }^{49}$ grew into the political controversy on theological grounds ${ }^{50}$. Thus, the controversy no more than fifteen years after Nicaea became the religious and political occasion for clarifying the proper relationship between the Church and the Christian Emperor ${ }^{51}$.

2. The principles of the pro-Arian political theory. The early pro-Arian views on the role of the Emperor in the Church represents Eusebius of Caesarea. He was a subordinationist. He considered Christ as lower to God ${ }^{52}$. For Eusebius the Emperor derives the source of the imperial authority from above ${ }^{53}$. He attributes to the Emperor a semblance of heavenly sovereignty and conformity

Christians during Constantius' lifetime. A letter from Cyril of Jerusalem (c. 313-386) to Constantius illustrates an example of such conviction.

${ }^{44} \mathrm{Cf}$. Socrates, HE IV 1-2. 6; Theodoretus, HE IV 11. See Barnes, Athanasius and Constantius, p. 161; Frend, The Rise of Christianity, p. 629.

${ }^{45}$ Cf. Socrates, HE IV 32; Sozomenus, HE VI 36. See Stertz, Themistius, p. 353; Williams, Christology and Church-State Relations (I), p. 25.

${ }^{46}$ Cf. Socrates, HE IV 1-2; IV 14-16; Theodoretus, HE IV 12. See Rahner, Church and State in Early Christianity, p. 62.

${ }^{47} \mathrm{Cf}$. Socrates, HE IV 22.

${ }^{48}$ Cf. ibidem IV 38; Theodoretus, HE IV 32.

${ }^{49}$ At the beginning controversy had only theological character. Cf. S. Laeuchli, The Case of Athanasius Against Arius, "Concordia Theological Monthly" 30 (1959) 405; P.S. Russell, Saint Gregory's Exegeses Against the Arians: Still a Viable Christian Tool, GOTR 39 (1994) fasc. 2, 123 130; M.F. Connell, Heresy and Heortology in the Early Church: Arianism and the Emergence of the Triduum, "Worship" 72 (1998) fasc. 2, 117-132; P. Smulders, A Bold Move of Hilary of Poitiers "Est ergo erans", VigCh 42 (1988) 121-131.

${ }^{50}$ At the early stage of the polemic the political machinations did not appear yet. They appeared in the course of the controversy. Cf. Brendan, The Arian Controversy, p. 55-56 and 64.

${ }^{51}$ Cf. Williams, Christology and Church-State Relations (I), p. 5; Frend, The Rise of Christianity, p. 529.

${ }^{52}$ Cf. Williams, Christology and Church-State Relations (I), p. 14-15.

${ }^{53} \mathrm{Cf}$. Eusebius Caesariensis, De laudibus Constantini II 1. 
to the monarchy of God ${ }^{54}$. The Emperor acted as the interpreter to the Word of $\operatorname{God}^{55}$. From the Word of God he received the administration of this world's affairs $^{56}$. It appears that in the teaching of Eusebius the royal law of the Christian Emperor was thought of as identical with the living and self-subsisting Word ${ }^{57}$. Eusebius seems to compare Christ and Constantine as the same instruments of manifestation of the only eternal $\operatorname{Logos}^{58}$. So, in the thought of Eusebius we may recognize the transformed Christian idea of the live law.

Eusebius allotted some special role for Emperor Constantine among the bishops in the Church. He stated that Constantine was "like a general bishop constituted by God" 59 . In the thought of Eusebius there was no place for two related but distinct societies - the Church and the state. George H. Williams asserts that it seems that Eusebius does not accept the separation between the Church and the state, which became Christian. For him Constantine's Empire was the reflection of the heavenly kingdom in the time ${ }^{60}$. Thus, we may assert that Eusebius transformed the ancient idea and elaborated the pro-Arian view on the role of the Emperor in the Church. He accepted primarily the Hellenistic ideas and the ideas of the Holy Scripture, but he differed significantly from the ante-Nicene pattern of relation between the Church and the state ${ }^{61}$. Francis Dvornik (1893-1975) noticed, that Eusebius was arming future theorists in their efforts to combine or to identify their own empires with the Church with dangerous weapons ${ }^{62}$.

To be more aware of the pro-Arian political theory, it would be desirable to examine the thought of other fourth century pro-Arian church dignitaries, but the sources are lacking ${ }^{63}$. It is known that the ideas of Eusebius of Caesarea supported Eusebius, the bishop of Nicomedia, who was a distant relation to the Constantinian family ${ }^{64}$. He had a great influence on a court. He pursued a policy of strengthening imperial authority over the Church. It is significant that he emphasized political insubordination among the charges he had

\footnotetext{
${ }^{54} \mathrm{Cf}$. ibidem III 5.

${ }^{55} \mathrm{Cf}$. ibidem II 4.

${ }^{56} \mathrm{Cf}$. ibidem I 6.

${ }^{57}$ Cf. ibidem III 6. See Williams, Christology and Church-State Relations (I), p. 15.

${ }^{58}$ Cf. Eusebius Caesariensis, De laudibus Constantini II 4-5. See Barnes, Constantine and Eusebius, p. 254. 271.

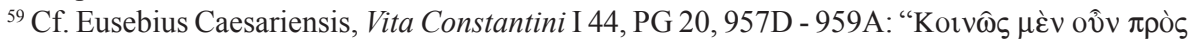

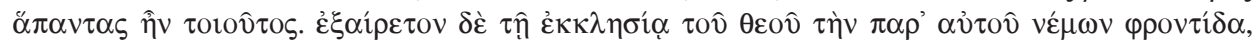

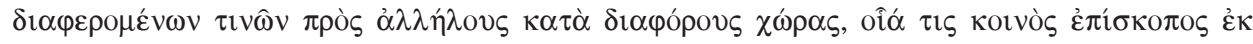

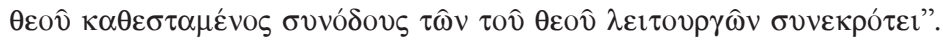

${ }^{60} \mathrm{Cf}$. Williams, Christology and Church-State Relations (I), p. 17-19.

${ }^{61}$ Cf. Dvornik, Early Christian and Byzantine Political Philosophy, vol. 2, p. 614-622. 644.

${ }^{62}$ Cf. ibidem, p. 616.

${ }^{63}$ Cf. Williams, Christology and Church-State Relations (I), p. 19.

${ }^{64} \mathrm{Cf}$. Ammianus Marcellinus, Res gestae XXII 9, 4.
} 
brought against his ecclesiastical adversaries ${ }^{65}$. It means that to some extent he identified the Church and the state.

The pro-Arian Christianity was always more prone to submit to the state's authority because of lack of the solid faith in Christ's divinity ${ }^{66}$. The conception a bishop has of Christ affects his attitude towards the Emperor ${ }^{67}$. The proArian accepted Christ as the Head of the Church, but in denying the full deity of Christ they were more inclined to emphasize the fact that while God was the Head of Christ, consequently, the established by God ruler was superior to the bishops instituted by Christ. Thus, the Empire is the earthly reflection of the Kingdom of God superior to Christ ${ }^{68}$. Before Constantine's death the proArians with their political conviction had already commended themselves as bishops more faithful to the Emperor than anti-Arians ${ }^{69}$.

From this point of view the pro-Arians were more disposed than Nicenes to accept the will of the Emperor as a canon, because in their conviction the canons of historical Christ could not have precedence over the living law of the Emperor ordained by the eternal $\operatorname{Logos}{ }^{70}$. Here the ancient motif of the live law is apparent. The pro-Arians considering the Emperor as the instrument of the Eternal Logos were disposed to regard the imperial approval of their elections as the necessary validation of their episcopal authority. The succession from Christ through bishops was less important for the pro-Arian bishops ${ }^{71}$. In this way the pro-Arian bishops strengthened the Emperor's authority over the Church and weakened the authority of the main ecclesiastical sees. The antiArian Lucifer of Cagliari ( $\uparrow$ c. 371$)$ mocks the pro-Arian bishops that they acknowledged the Emperor as "bishop of bishops"72. Athanasius also declared that the pro-Arians had no other king but the Emperor ${ }^{73}$.

In such perspective the pro-Arians commonly were not reluctant to be the appointees of the Emperor and they were willingly translated to the larger $\operatorname{sees}^{74}$. For example, Eusebius of Nicomedia was appointed as the bishop of

${ }^{65}$ Cf. Socrates, HE I 27; I 23; I 35; Sozomenus, HE II 22; Athanasius, De synodis 21. See Williams, Christology and Church-State Relations (I), p. 19; Barnes, Athanasius and Constantius, p. 22.

${ }^{66}$ Cf. Rahner, Church and State in Early Christianity, p. 63-64.

${ }^{67}$ Cf. Williams, Christology and Church-State Relations (I), p. 3.

${ }^{68}$ Cf. idem, Christology and Church-State Relations (II), p. 15. The docile position of the pro-Arian bishops towards the Emperor mocks Lucifer of Cagliari in his works: De non conveniendo cum haereticis; Moriendum esse pro Dei Filio; De non parcendo in Deo delinquentibus.

${ }^{69} \mathrm{Cf}$. Athanasius, Historia Arianorum 33. See Williams, Christology and Church-State Relations (I), p. 24.

${ }^{70}$ Cf. Williams, Christology and Church-State Relations (I), p. 14. 18.

${ }^{71}$ Cf. idem, Christology and Church-State Relations (II), p. 6-7 and 10.

${ }^{72}$ Cf. Lucifer Calaritanus, Moriendum esse pro Deo filio, PL 13, 1032C: "Quid ad haec respondes, Constanti? Cui crebro sunt acclamantes Ariani dogmatis tui episcopi, episcopum te esse episcoporum $[\ldots]$ ".

${ }^{73}$ Cf. Athanasius, Historia Arianorum 33.

${ }^{74} \mathrm{Cf}$. ibidem 74-75. 
Constantinople (339) by the Emperor without decision of a council ${ }^{75}$. Thus, the pro-Arian bishops gradually lost the connection with people in favour of the Emperor ${ }^{76}$.

It seems that after Arius' heresy had arisen, a majority of bishops of Asia did not condemn his cause ${ }^{77}$. They were led by the pro-Arian Eusebius of Caesarea and Eusebius of Nicomedia, who had acquired the reputation of a statesman ${ }^{78}$. While Constantine was alive a few could not accept the Nicene symbol as the criterion of the true faith. The opposition to the Symbol was faint because the Emperor demanded himself to accept it. Moreover, the Symbol itself was ambiguous and the canons did not interfere in the power of church dignitaries ${ }^{79}$.

But Arius and his adherents did not want to renounce their views even for the Emperor ${ }^{80}$. Arius and his friends chose exile instead of signing the definition of the faith ${ }^{81}$. Nevertheless Eusebius of Caesarea after consideration subscribed the definition of the faith. He explained the word ónoovoros in a letter sent to his people and attempted to justify his support of the Symbol. He explained the term to the people and said that the Emperor had introduced the term ${ }^{82}$. Bishops Eusebius of Nicomedia and Theognis of Nicaea $\left(4^{\text {th }} \mathrm{c}\right.$. $)$ and their followers declared themselves unable to assent to this Creed and did not

${ }^{75}$ Cf. Socrates, HE II 7; Theodoretus, HE I 18. After Eusebius' death (c. 341) people introduced Paul (bishop of Constantinople: 337-339. 341-342. 346-350, $\uparrow$ after 350), but the pro-Arians installed Macedonius (bishop of Constantinople: 342-346. 351-360, $\uparrow$ after 360). Constantius did not like both, especially Macedonius, because he was ordained without the permission of the Emperor. See Socrates, HE II 12-13.

${ }^{76} \mathrm{Cf}$. Athanasius, Historia Arianorum 2-3. See Williams, Christology and Church-State Relations (II), p. 10-11.

${ }^{77} \mathrm{Cf}$. Gibbon, The Decline and Fall of the Roman Empire, p. 683; Rahner, Church and State in Early Christianity, p. 51.

${ }^{78} \mathrm{Cf}$. Athanasius, Contra Arianos 59. See Gibbon, The Decline and Fall of the Roman Empire, p. 683.

${ }^{79} \mathrm{Cf}$. H. Chadwick, Faith and Order at the Council of Nicaea: A Note on the Background of the Sixth Canon, HTR 53 (1960) fasc. 3, 175; О. Кащук, Роль Римського єпископа у засудженні аріанського вчення на I Вселенському Соборі в Нікеї, “Наукові записки Національного університету «Острозька академія»: серія «Історичне релігієзнавство»" 7 (2012) 93-94.

${ }^{80} \mathrm{Cf}$. Novak, Christianity and the Roman Empire, p. 172; Gibbon, The Decline and Fall of the Roman Empire, p. 687.

${ }^{81}$ Five bishops did not accept the Symbol: Eusebius of Nicomedia, Theognis of Nice, Maris of

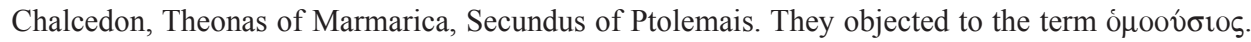
They did not subscribe to the deposition of Arius. The council of Nicaea anathematized Arius and all who adhered to his opinions. At the same time the Emperor by his edict sent Arius himself into exile, together with Eusebius and Theognis and their followers. Cf. Socrates, HE I 8. Sozomenus declares that although Eusebius of Nicomedia and Theognis of Nice assented to the document of this faith set forth by the Council, they neither agreed nor subscribed to the deposition of Arius. The Emperor punished Arius with exile and commanded Eusebius and Theognis to quit the cities whereof they were bishops. See Sozomenus, HE I 21.

${ }^{82}$ Cf. Eusebius Caesariensis, Epistula ad ecclesiam Caesariensem 7, ed. A. Baron - H. Pietras, in: Dokumenty Soborów Powszechnych. Tekst grecki, łaciński, polski, układ i opracowanie A. Baron - H. Pietras, DSP 1, Kraków 2005, 56; Socrates, HE I 8. See Kelly, Early Christian Creeds, p. 
support the deposition of Arius. They were banished to exile ${ }^{83}$. Shortly after their banishment they expressed their desire to be reunited with the Church and after sending profession of the faith to the main bishops of the Church, they were readmitted to their sees by the imperial edict ${ }^{84}$.

Within two years the allies of Arius gained an ascendancy in the Eastern Church and prepared for his readmission to communion. Eusebius of Caesarea played a central role. He presided over a council at Antioch on which Eustathius was deposed ${ }^{85}$. Arius and his fellow priest Euzoius submitted to Emperor Constantine's formula and pretended to accept the Nicene Creed. It secured their rehabilitation ${ }^{86}$. Constantine summoned the council at Nicomedia (327-328). He was present in person. Arius and his friends were readmitted to communion ${ }^{87}$.

In this perspective it should be noticed, that theoretical principles of the proArian political theory were not completely fulfilled in practice. Some incongruity with the theoretical views on superiority of the Emperor's power in the Church became obvious in the conduct of the pro-Arian bishops. They preferred their own views to absolute submission to the Emperor. It means that in reality they recognized the Emperor as the head of the Church, but not as the absolute and supreme head. They seemed to consider the Emperor as the instrument for their theology propagation and looked for partiality for their views. They managed to achieve this by the dexterous management of their leaders ${ }^{88}$.

In reality Arius and his fellows remained dissatisfied with the Creed,

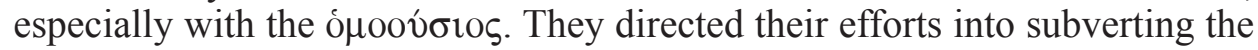
Symbol. With the aid of the Emperor they began to install the bishops of their own views and compose new creeds. Thus, they intended to hold councils at their pleasure ${ }^{89}$.

214-215. On the analysis of the letter of Eusebius cf. Kelly, Early Christian Creeds, p. 220-226. See Кащук, Роль Римського єпископа, р. 97-98.

${ }^{83}$ Cf. Socrates, HE I 8.

${ }^{84}$ Cf. ibidem I 8; I 14; II 16.

${ }^{85}$ Cf. Eusebius Caesariensis, Vita Constantini III 59-62; Athanasius, Historia Arianorum 4; Socrates, HE I 24; Sozomenus, HE II 19; Theodoretus, HE I 20.

${ }^{86}$ Cf. Socrates, HE I 26; Sozomenus, HE II 27. See Kelly, Early Christian Creeds, p. 189-190. Arius himself restated and modified his opinions more than once. Cf. Barnes, Athanasius and Constantius, p. 14. More details on Arius' exile and recall see T.D. Barnes, The exile and recalls of Arius, JTS 60 (2009) 109-129.

${ }^{87} \mathrm{Cf}$. Philostorgius, HE II 7. More on the Constantine's politics towards pro-Arians see S. Bralewski, Polityka Konstantyna Wielkiego wobec arian po soborze w Nicei: Naghy zwrot czy kontynuacja?, VoxP 18 (1998) t. 34-35, 335-355.

${ }^{88} \mathrm{Cf}$. Athanasius, Historia Arianorum 7; 37-38; Theodoretus, HE II 2. See Gibbon, The Decline and Fall of the Roman Empire, p. 695. 697; Rahner, Church and State in Early Christianity, p. 49; Frend, The Rise of Christianity, p. 533.

${ }^{89} \mathrm{Cf}$. Athanasius, De synodis 21-22. See Athanasius, Historia Arianorum 4; Socrates, HE I 24; II 2; Sozomenus, HE II 19; Theodoretus, HE I 20. The main agenda of a council was to promulgate a universally acceptable creed and to solve disciplinary problems. 
The pro-Arians had their own criterion of validity of the council decision in the sphere of doctrine. According to their views, the faith could be decided ever anew by majority decisions, not by decisions of the delegates of the universal $\mathrm{Church}^{90}$. The definitive approbation issued by the Emperor made the decisions valid. We should notice that sometimes even the personal views were taken as an exposition of faith ${ }^{91}$. Without a solid universal criterion of true faith among the sectaries a spirit of discord and inconstancy emerged: in the course of less than half a century over a dozen creeds were composed ${ }^{92}$.

The custom of synodal creeds was developed, established at Antioch in the early 325 and then continued at the Council of Nicaea and in the synods after Nicaea ${ }^{93}$. Since a feature of the period between the Councils of Nicaea (325) and Constantinople (381) there was a large number of controversial assemblies of bishops convened by the Emperor ${ }^{94}$, we should look attentively at the series of pro-Arian synods for making more complete presentation of the picture of the pro-Arian attitude towards the Emperor.

\section{A series of synods as demonstration of the pro-Arian political} implementation. As to Church-state relation the synod of Tyre (335) was the most demonstrative. Adversaries of Athanasius, making use of the situation that he did not want to accept Arius to Alexandria, slandered him before the Emperor $^{95}$. Constantine ordered a council of bishops to meet at Tyre. The consul Dionysius was to supervise ${ }^{96}$. The bishops deposed Athanasius ${ }^{97}$. Then the bishops from Tyre adjourned to Jerusalem where the same bishops confirmed Arius' admission to communion as a holder of the orthodox theological views ${ }^{98}$. According to Athanasius, the council at Jerusalem was the

${ }^{90}$ Cf. Theodoretus, HE II 13. See Williams, Christology and Church-State Relations (I), p. 13.

${ }^{91} \mathrm{Cf}$. Socrates, HE II 40.

${ }^{92}$ Cf. Athanasius, De synodis 14; Socrates, HE II 41. See Fiedrowicz, Teologia Ojców Kościoła, p. 246-247 and 357-360. In the second part of De synodis Athanasius quotes a long series of creeds to show how the pro-Arians have tried to replace the Nicene formula, see Athanasius, De synodis II 22-32. According to T.D. Barnes (Athanasius and Constantius, p. 134) Athanasius' comments on the documents are misleading, for not all are creeds, and he presents them ignoring their political and theological contexts. In Athanasius' exposition, all these documents are the work of the same group of bishops, perennially dissatisfied with their existing creed.

${ }^{93}$ Cf. Kelly, Early Christian Creeds, p. 205-211.

${ }^{94}$ Cf. Athanasius, De synodis 22. See Kelly, Early Christian Creeds, p. 263.

${ }^{95} \mathrm{Cf}$. Socrates, HE I 27; Theodoretus, HE I 25-26.

${ }^{96}$ Cf. Eusebius Caesariensis, Vita Constantini IV 41-42; Socrates, HE I 28; Theodoretus, HE I 26-28. See Barnes, Athanasius and Constantius, p. 22.

${ }^{97} \mathrm{Cf}$. Socrates, HE I 32.

${ }^{98}$ Cf. Eusebius Caesariensis, Vita Constantini IV 43-45; Socrates, HE I 33; Sozomenus, HE II 27; Theodoretus, HE I 29; Athanasius, Historia Arianorum 21. The Emperor issued an absolute command that Arius should be admitted to the communion in the cathedral of Constantinople, but Arius died the day before admittance. See Socrates, HE I 38. 
beginning of the pro-Arian councils ${ }^{99}$. But Emperor Constantine had doubts about the rightness of Athanasius' deposition on the basis of his complaints and commanded the bishops to present themselves in court at Tyre. Officially the decisions of the council of Tyre had no legal force, because the Emperor had made them null. He was persuaded by Athanasius that it had proceeded improperly and unfairly. Nevertheless the Emperor changed his mind and banished Athanasius to Treves. Although Athanasius was sent to Gaul, he was still the lawful bishop of Alexandria, because the decision of the council was nulled. He was banished by the decision of the Emperor ${ }^{100}$.

For the future relationship between the Church and the state in the East, the council of Tyre was exemplary. It had been summoned by the Emperor and organized like a court of justice. It was supervised by the imperial official. The Emperor had intervened directly in a matter of the Church discipline and though sentence had been pronounced by the bishops, their proceedings were supervised by a layman ${ }^{101}$. This was to be the pattern for all the councils in the future ${ }^{102}$. The substantive matters and the course of the council were in the hands of bishops but the last verdict belonged to the Emperor ${ }^{103}$. The pro-Arian bishops accepted such politics.

In 337 Athanasius encouraged by the Letter of Constantine the Younger (317-340, the emperor since 337), returned to Alexandria ${ }^{104}$. In this way the Emperor showed that he had an authority to restore a bishop to his see without a council. The enemies of Athanasius convoked a council of bishops (The Dedication Council which met in 341 at Antioch). A legal force was given to the council by Emperor Constantius. The Council found Athanasius' return to his see improper and contrary to the ecclesiastical canon on the grounds that he had returned without the sanction of a synod of bishops ${ }^{105}$. The council selected Gregory of Cappadocia to be the new bishop of Alexandria (bishop: 339-346) ${ }^{106}$. In this way the decision of the Emperor which allowed the exiled

\footnotetext{
${ }^{99} \mathrm{Cf}$. Athanasius, De synodis 21-22.

${ }^{100}$ Cf. Socrates, HE I 34; Theodoretus, HE I 29. See Barnes, Athanasius and Constantius, p. $173.23-25$.

${ }^{101}$ Cf. Socrates, HE I 28; Sozomenus, HE II 25. See Barnes, Athanasius and Constantius, p. 170; Frend, The Rise of Christianity, p. 527.

${ }^{102} \mathrm{Cf}$. Frend, The Rise of Christianity, p. 527.

${ }^{103}$ Cf. Athanasius, Historia Arianorum 33. See Williams, Christology and Church-State Relations (I), p. 24.

${ }^{104}$ Cf. Socrates, HE II 3; Sozomenus, HE III 2; Theodoretus, HE II 1. See Barnes, Athanasius and Constantius, p. 36; idem, Constantine and Eusebius, p. 263-264. This is only one example between 324 and 361 when a synodical condemnation was openly reversed by imperial edict, when the Emperor issued an edict restoring all the bishops exiled under his father. Cf. Barnes, Athanasius and Constantius, p. 173.

${ }^{105}$ Cf. Socrates, HE II 8-10; Sozomenus, HE III 5; Athanasius, Epistula encyclica II 1. See Barnes, Athanasius and Constantius, p. 36; idem, Constantine and Eusebius, p. 264.

${ }^{106}$ Cf. Socrates, HE II 10-11.
} 
bishops to return to their sees was regarded as canonically invalid ${ }^{107}$. This is another example of inconsequent politics of the pro-Arians concerning the Emperor. On the contrary, the absence of the bishops of Jerusalem and Rome $^{108}$ on the council which was to define the faith, also testifies the proArian disrespect for the main ecclesiastical sees.

The bishops promulgated four creeds ${ }^{109}$. The only official statement of the faith ratified by the Dedication Council was the so-called Second Creed of Antioch $^{110}$. It is the first of a dozen creeds that were compiled during Constantius' reign to rid the Church of the consubstantial formula. It anathematized specific Arian teachings. Bishops denied that they were the followers of Arius. They declared that they were faithful to the Scripture ${ }^{111}$. But the formula was not accepted universally. William H.C. Frend states, that if this formula had been accepted, it would have had a positive effect on the future history of the Church, for it represented a meeting of Alexandrian and Antiochene ideas ${ }^{112}$. The doctrinal decision of the council manifests that the definition of the true faith was of great importance for the pro-Arian bishops.

The doctrinal and political position of the pro-Arians was being clearly manifested in the course of time. Presumably in the winter of 342-343 the western Emperor forced the eastern Constantius to assemble a joint council of eastern and western bishops. The council had to meet at Serdica in the summer of 343. The eastern bishops were accompanied by two imperial officers and stayed in the imperial residence in the city, thus emphasizing the progressive integration of the Church and the state in the eastern provinces of Empire ${ }^{113}$. There was no agreement ${ }^{114}$. A profession of faith was appended by both the easterners ${ }^{115}$ and the westerners ${ }^{116}$. In this way the first meeting of eastern and

${ }^{107}$ Cf. Barnes, Athanasius and Constantius, p. 46. 173.

${ }^{108}$ Cf. Socrates, HE II 8.

${ }^{109}$ Cf. Athanasius, De synodis 22-25. See Kelly, Early Christian Creeds, p. 265-273.

${ }^{110} \mathrm{Cf}$. Athanasius, De synodis 23.

${ }^{111}$ Cf. ibidem 22-23.

${ }^{112} \mathrm{Cf}$. Frend, The Rise of Christianity, p. 530. In its main drift the creed is resolutely anti-Sabellian. To interpret this as disloyal to Nicaea is misconceive the situation. The ópoov́бios had not yet become a brand of discord. The real battle at this period was between two misrepresentations of the truth, an Athanasian caricature of the pro-Arians as utter Arians, and an Eastern caricature of the Athanasian position as indistinguishable from that of Marcellus. See Kelly, Early Christian Creeds, p. 268-271. 274; Barnes, Athanasius and Constantius, p. 69.

${ }^{113}$ Cf. Socrates, HE II 20; II 22; Theodoretus, HE II 6; Athanasius, Historia Arianorum 15-17. See Barnes, Athanasius and Constantius, p. 69. 128.

${ }^{114}$ Cf. Socrates, HE II 20; Theodoretus, HE II 6; Athanasius, Contra Arianos 37. See Barnes, Athanasius and Constantius, p. 72-76.

115 This was none other than the so-called Fourth Creed of Antioch. Cf. Kelly, Early Christian Creeds, p. 275-277.

${ }^{116}$ Cf. Theodoretus, HE II 6; Sozomenus, HE III 12. See Kelly, Early Christian Creeds, p. $277-$ 279. It is a striking fact that even the Western formula of Serdica does not refer either to Nicaea or to ómoov́oıs. See Kelly, Early Christian Creeds, p. 283. 
western bishops had ended in schism. The difference between pro-Arian and anti-Arian attitudes towards the Christian Emperor was underscored ${ }^{117}$. The pro-Arians continued to recognize the leadership of the Emperor also in the sphere of framing of the Church doctrine.

Constantius still tried to prepare the western bishops against Athanasius on the councils first at Arles in 353 and then at Milan in $355^{118}$. In a process which lasted several years, officials were compelling the Christians to accept the Sirmian decisions, as subscribed at Arles, and subsequently at Milan ${ }^{119}$. In 357 the so-called Blasphemy of Sirmium nearly supplied the formula. The council was assembled by Constantius's adherents. There was confirmed a prohibition

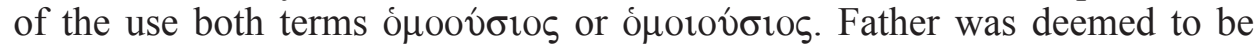
greater than the Son and the Son as subordinated to the Father together with all things which the Father had subordinated to $\mathrm{Him}^{120}$. Anathemas of Arianism are for the first time conspicuously absent here. The Nicene creed was declared as unorthodox and unlawful ${ }^{121}$. That was the victory of "anomoeans", who were led by Aetius (c. 300 - c. 366) and Eunomius (c. 335-395) with the support of the Emperor.

The position of "anomoeans" was contrary to the position of great majority of traditional pro-Arian bishops ${ }^{122}$. By the spring of 358 they had found a leader in Basil (c. 300 - c. 364), the bishop of Ancyra. For them the ideas of the radical doctrines of Aetius and Eunomius were completely unacceptable ${ }^{123}$. At the council held in Ancyra in April of 358 they declared that the Son was like

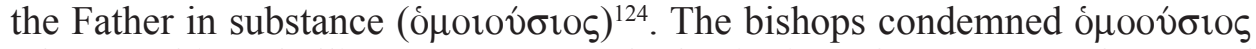
when used in Sabellian sense. It was the beginning of movement of many of

${ }^{117}$ Cf. Barnes, Athanasius and Constantius, p. 80; Frend, The Rise of Christianity, p. 531. 534; Gibbon, The Decline and Fall of the Roman Empire, p. 703.

${ }^{118}$ Cf. Ammianus Marcellinus, Res gestae XV 7, 10. See Frend, The Rise of Christianity, p. 534; Barnes, Athanasius and Constantius, p. 115. At Milan from the faint bishops Constantius obtained condemnation of Athanasius. Those, who refused, were banished, among them pope Liberius (352366). Cf. Sozomenus, HE IV 11; Theodoretus, HE II 12-17; Athanasius, Historia Arianorum 35-40; Ammianus Marcellinus, Res gestae XV 7, 6-10. Liberius capitulated to Constantius' demands in 357. See Athanasius, Historia Arianorum 41; Barnes, Athanasius and Constantius, p. 118.

${ }^{119}$ Cf. Athanasius, Historia Arianorum 31-32.

${ }^{120}$ Cf. Socrates, HE II 29-31; Sozomenus, HE IV 6; Athanasius, De synodis 28; Hilarius Pictaviensis, De synodis 11; idem, Excerpta ex opere historico VI-IX. Hosius of Cordova (c. 257-359) signed the definition and pope Liberius may have also. See Hilarius Pictaviensis, Excerpta ex opere historico V-VI; Athanasius, Historia Arianorum 41; Contra Arianos 89; Sozomenus, HE IV 6; Hieronymus, De viris illustribus 97.

${ }^{121}$ Cf. Kelly, Early Christian Creeds, p. 287.

${ }^{122}$ Cf. Socrates, HE II 39-40; II 45. See Chadwick, The Early Church, p. 140-141; Frend, The Rise of Christianity, p. 536; Kelly, Early Christian Creeds, p. 288.

${ }^{123}$ Cf. Barnes, Athanasius and Constantius, p. 138.

${ }^{124}$ Cf. Sozomenus, HE IV 13. See Kelly, Early Christian Creeds, p. 288; Barnes, Athanasius and Constantius, p. 139-141. 
the eastern bishops towards Athanasius' views ${ }^{125}$. Basil requested the Emperor to convene a council to confirm the established doctrine ${ }^{126}$.

But the radical pro-Arian minority of bishops who were prepared to accept

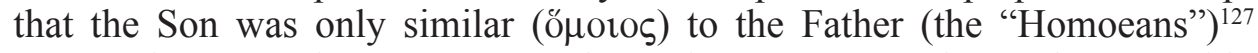
managed to turn the Emperor to themselves. In May of 359 the assembly at Sirmium in the Emperor's presence composed a statement (the Fourth of Sirmium) as a working basis to be submitted to a council ${ }^{128}$. It avoided the term ovं $\sigma i \alpha$ as unscriptural. Its first lines started with a statement which underscores the role of the Emperor: "The Catholic faith was expounded at Sirmium in the presence of our lord Constantius [...]"129. The statement testifies that for the radical pro-Arian bishops the Emperor was the absolute head of the Church. This creed gave an expression to the new formula of similarity ("Homoean") supported by the Emperor ${ }^{130}$.

The two parallel councils were proposed to be held in the East and West - Seleucia and Ariminum (359). They were intended to finish the process of definition of the faith of the Church. Imperial commissioners had to supervise the councils and influence their proceedings. The bishops assembled at councils were expected to ratify the document presented to them ${ }^{131}$.

The large majority of the western bishops at Ariminum reaffirmed the Nicene creed $^{132}$. After the commissioner had applied coercion the bishops

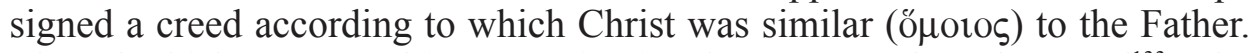
Then the bishops were driven to Nice in Thrace to confirm the creed ${ }^{133}$. The place of the subscription of this creed had been craftily chosen: hence the new creed subscribed at Nice could be represented as a "Nicene" creed, and it is reported that the similarity of the name proved to be capable of deceiving some bishops ${ }^{134}$. The council of Ariminum did not bring mutual understanding ${ }^{135}$.

${ }^{125}$ Cf. Frend, The Rise of Christianity, p. 540.

${ }^{126}$ Cf. Sozomenus, HE IV 13. See Kelly, Early Christian Creeds, p. 288-291.

${ }^{127}$ Cf. Kelly, Early Christian Creeds, p. 288-291.

${ }^{128}$ Cf. Athanasius, De synodis 8; Socrates, HE II 30; II 37. See Kelly, Early Christian Creeds, p. 288-291.

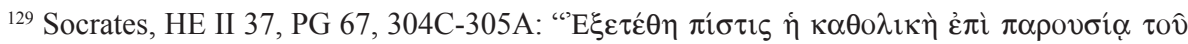

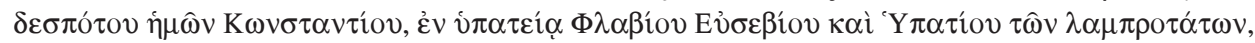

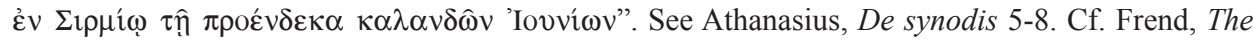
Rise of Christianity, p. 540; Barnes, Athanasius and Constantius, p. 134.

${ }_{130}$ Cf. Kelly, Early Christian Creeds, p. 290-291; Barnes, Athanasius and Constantius, p. $144-145$.

${ }^{131} \mathrm{Cf}$. Athanasius, De synodis 1-10. See Barnes, Athanasius and Constantius, p. 140-145.

${ }^{132}$ Cf. Athanasius, De synodis 10; Socrates, HE II 37; Sozomenus, HE IV 18.

${ }^{133}$ Cf. Sulpitius Severus, Chronicorum lib. II 41-43; Athanasius, De synodis 3-9; Theodoretus, HE II 15-16; Socrates, HE II 37. See Kelly, Early Christian Creeds, p. 291; Barnes, Athanasius and Constantius, p. 145-146.

${ }^{134}$ Cf. Socrates, HE II 37; Sozomenus, HE IV 19.

${ }^{135}$ Cf. Socrates, HE II 40. 
The eastern bishops attended the council of Seleucia with the imperial officers. The great majority were adherents of ópotoviotos, the minority favored önotos. The council split into two groups ${ }^{136}$. After the interference of the imperial commissioner the council accepted a creed almost identical to the "Dated" composed at Sirmium in May of 359. Not all the bishops agreed with the decisions. Constantius admitted coercion to accept the creed. In December of 359, the representatives of both councils - Ariminum and Seleucia - subscribed the creed which established a new imperial "homoean" doctrine. Thus, the victory of o $\mu$ oroৎ was formally completed ${ }^{137}$.

The formula was definitely confirmed by a further meeting at Constantinople in January of 360. The council promulgated the creed, based on that of Nice, which rejected all previous creeds and forbade the formulation of the new ones in the future. This was the last of the long line of creeds promulgated in this period. It became the official formula of the imperial Church ${ }^{138}$. It seemed that the Emperor and the radical Arian bishops prevailed in the Church. According to Jerome the world "awoke with a groan to find itself Arian"139.

After Constantius's death in 361 the new official creed of 360 lost its imperial patron ${ }^{140}$. By the middle of 362 at Alexandria Athanasius gathered a council of bishops. There were also the adherents of the of formula of Nicaea was accepted with the explicit proviso that no Sabellianism was implied, and the distinction of the "individualities" ( $\delta$ ió $\sigma \tau \alpha \sigma \iota \varsigma$ ) of the Persons of the Trinity was to be acknowledged ${ }^{141}$. The problem was solved to the satisfaction of the majority of the theologically aware eastern bishops.

The final doctrinal position of the majority of the so-called pro-Arian bishops showed their real attitude towards the Emperor: they did not recognize him as the absolute head of the Church and were loyal to the Emperor to a certain extent, only if he had supported the theological decisions which were consonant with the spirit of Tradition. But they were not absolutely free in making the theological decision because of their acknowledgment of the special role of the Emperor in the Church.

${ }^{136}$ Cf. ibidem II 39; Athanasius, De synodis 12.

${ }^{137}$ Cf. Socrates, HE II 39-41; Sozomenus, HE IV 23; Sulpitius Severus, Chronicorum lib. II 45. See Barnes, Athanasius and Constantius, p. 146-148; Kelly, Early Christian Creeds, p. 292-293.

${ }^{138}$ Cf. Socrates, HE II 41; Sozomenus, HE IV 26. See Kelly, Early Christian Creeds, p. $293-$ 294; Barnes, Athanasius and Constantius, p. 148-149.

${ }^{139}$ Cf. Hieronymus, Adversus Luciferianos 19, PL 23, 181B: “Coeperunt postea Valens et Ursacius, caeterique nequitiae eorum socii, egregii videlicet Christi sacerdotes, palmas suas jactitare, dicentes se Filium non creaturam negasse, sed simile caeteris creaturis. Tunc usiae nomen abolitum est: tunc Nicaenae fidei damnatio conclamata est. Ingemuit totus orbis, et Arianum se esse miratus est".

${ }^{140}$ Cf. Sozomenus, HE VI 4. See Barnes, Athanasius and Constantius, p. 152.

${ }^{141}$ Cf. Athanasius, Tomus ad Antiochenos 6-9; Sozomenus, HE V 12. See Frend, The Rise of Christianity, p. 605; Kelly, Early Christian Creeds, p. 284; Chadwick, The Early Church, p. 146; Barnes, Athanasius and Constantius, p. 122-123 and 134-135.152; Fiedrowicz, Teologia Ojców Kościoła, p. 241-243. 
After 361 the main stream of the Church doctrine in the East was moving towards Nicaea. Arianism was divided and it was getting weak in spite of the efforts of Emperor Valens to revive it. There was an urgency to summon a council to confirm the definition of faith acceptable to all who cherished sound theology. It could be accomplished only with the support of well disposed Emperor Theodosius (c. 347-395, the emperor since 379) ${ }^{142}$. Arianism degraded to the level of religious sect, even though it had many adherents in Constantinople ${ }^{143}$. Till 381 the classic Arianism was dead at least as an intellectual force within the Greek-speaking eastern Empire ${ }^{144}$. But the custom to admit the Emperor to intervene in the sphere of Church doctrine remained alive and "nolens volens" necessary at the time.

In conclusion it is to be said that the attitude of the pro-Arian bishops towards the Emperor was the position neither of an absolute submission nor the whole independence. It seems that the bishops were at the crossroads. On the one hand, they were entrenched in the ancient biblical and Hellenistic political ideology which also prevailed in the Christian East even after the Emperor had become a Christian, on the other hand - they endeavored to remain faithful to Church Tradition in the sphere of doctrine ${ }^{145}$. Their attitude towards the Emperor differed from the model elaborated during the anteNicene pattern of relation between the Church and the state. It appears that their political conviction concerning their loyalty to the Emperor did not allow them to be wholly faithful to the ecclesiastical Tradition. Volatility of the Emperor evoked the bishop's inconstancy. The solid evidence of their sound traditional opinions is the definition of the synod held at Antioch in 341 and then at Ancyra in 358. On the contrary, a dozen of creeds is a witness of their acceptance of the Emperor's will and, in consequence, incompetence in the sphere of doctrine ${ }^{146}$. They were openly denouncing the synods called by themselves ${ }^{147}$. After the death of Constantius, a patron of Arianism, the so-called pro-Arian bishops for some time achieved theological liberty. Then their movement towards Nicaea became clear in 362. This movement proved that without the intervention of the state the Arian heresy would have withered and died long ago ${ }^{148}$. The end of the Arian controversy did not discharge the Church of intervention of the Emperor, but underscored the role of the Emperor at councils. Whether one likes it or not the orthodoxy was promulgated by the Council at Constantinople (381) with the Emperor's support and intervention.

${ }^{142}$ Cf. Socrates, HE V 8; Sozomenus, HE VII 4-5; VII 7; VII 9; VII 12. See Dvornik, Early Christian and Byzantine Political Philosophy, vol. 2, p. 768-769.

${ }^{143}$ Cf. Sozomenus, HE V 20; V 23-24; VII 6. See Frend, The Rise of Christianity, p. 640.

${ }^{144}$ Cf. Socrates, HE V 20. See Barnes, Athanasius and Constantius, p. 132.

${ }^{145} \mathrm{Cf}$. Socrates, HE I 33.

${ }^{146}$ Cf. Fiedrowicz, Teologia Ojców Kościoła, p. 246-247.

${ }^{147} \mathrm{Cf}$. Theodoretus, HE II 18.

${ }^{148}$ Cf. Athanasius, Historia Arianorum 64-72. 
Its arrangement was confirmed by the Emperor's approbation ${ }^{149}$. There was no other possibility. The Eastern Church in the period of reception of the Nicene Christology was accustomed to such a practice. Thus, the pro-Arian attitude towards the Emperor sowed the seeds of future Byzantine Caesaropapism ${ }^{150}$.

\section{STANOWISKO BISKUPÓW PROARIAŃSKICH WOBEC CESARZA W DOBIE RECEPCJI CHRYSTOLOGII NICEJSKIEJ (325-381)}

\section{(Streszczenie)}

Sobór Nicejski nie położył kresu kontrowersji ariańskiej. Po soborze nastąpił długi okres walki o recepcję chrystologii nicejskiej. Kontrowersja stała się przedmiotem zainteresowania cesarza, ponieważ postrzegano ją jako zagrożenie dla jedności cesarstwa. $Z$ tego powodu zwyczaj ingerowania cesarza w sprawy kościelne stawał się coraz częstszy i nawet dotyczył nauki Kościoła. Taka sytuacja wywołała reakcję biskupów i stała się okazją do określenia roli cesarza w Kościele. W IV w. istniały dwa główne stanowiska w tej kwestii - biskupów proariańskich i antyariańskich. Głównym celem artykułu było ukazanie stanowiska biskupów proariańskich wobec cesarza. Analiza źródeł historycznych i literatury wykazała, że ich postawa wobec cesarza nie była ani bezwzględnym podporządkowaniem się ani całkowitą niezależnością. Ich model stosunków między Kościołem a państwem został zainspirowany przez Euzebiusza z Cezarei, który przeniósł na grunt chrześcijański antyczną, hellenistyczną teorię polityczną oraz hebrajską koncepcję władcy. W kontekście antycznych idei cesarz jako żywe prawo posiadał szczególną rolę w Kościele. Przejawiała się ona szczególnie na synodach. Biskupi proariańscy dopuścili cesarza do interweniowania nawet W sferę kościelnej doktryny. Ich postawa wobec cesarza znacznie różniła się od modelu wypracowanego w dobie przednicejskiej. Z drugiej jednak strony biskupi proariańscy starali się dochować wierności Tradycji Kościoła. $Z$ tego powodu nie mogli uznać cesarza za jego głowę. Zakończenie kontrowersji ariańskiej nie uwolniło Kościoła od zależności od cesarza. Kościół Wschodni w okresie recepcji Credo Nicejskiego został niejako zaprogramowany pod kątem uzależnienia od cesarza. W ten sposób postawa proariańskich biskupów legła u podstaw przyszłego bizantyńskiego cezaropapizmu.

Key words: Church, Emperor, state, council, synod, creed, politics.

Słowa kluczowe: Kościół, cesarz, państwo, sobór, synod, credo, polityka.

${ }^{149}$ Cf. Socrates, HE V 8; Sozomenus, HE VII 12. On theology of the Creed of the Council of Constantinople (381) see Fiedrowicz, Teologia Ojców Kościoła, p. 248-251.

${ }^{150}$ Cf. Williams, Christology and Church-State Relations (I), p. 10; Novak, Christianity and the Roman Empire, p. 219-220. 
